\title{
Geographic Targeting and Normative Frames: Revisiting the Equity of Conditional Cash Transfer Program Distribution in Bolivia, Colombia, Ecuador, and Peru
}

\author{
Mathieu J. P. Poirier ${ }^{1,2}$
}

\begin{abstract}
Background: Four Andean countries of Bolivia, Colombia, Ecuador, and Peru introduced national health-focused conditional cash transfer (CCT) programs in the 2000s. This study probes whether policymakers in these countries targeted CCT programs to subregions with the highest prevalence of ill-health or those with the lowest socioeconomic status (SES) to evaluate the equity of geographic targeting and means-testing, as well as the potential role of normative frames, bounded rationality, and clientelism as explanatory mechanisms for inequities in social spending.

Methods: The distribution of vaccination coverage, underweight, stunting, and child deaths is established both within and between subnational regions and SES quintiles from 1998 to 2012 using every available nationally representative household survey. The equity of CCT program targeting and strength of association with subregional SES and health outcomes are measured using generalized entropy index decomposition and meta-regression. Finally, simple predictive models for CCT targeting are created using lagged subregional SES, health outcomes, and concentration indices.

Results: Bolivia and Peru both effectively targeted at-risk subregions, but subregions in Peru with no CCT program coverage result in higher mistargeting rates for the country as a whole. Only Bolivia failed to attain $C \subset T$ coverage concentration indices that are at least as large as the health inequalities they are targeting. Despite this insufficient progressivity, Bolivia has the most efficient subregional targeting, while the lowest rates of mistargeting for child deaths are found in Colombia and Ecuador. Finally, the simple predictive model performs as well or better than observed CCT coverage distribution for every country, year, and outcome.

Conclusions: Both Peru and Ecuador have targeted programs to their poorest populations effectively, demonstrating that this is possible with both universal and geographic targeting. No clear evidence of clientelism was found, while the dominant normative frame underlying CCT program targeting decisions appears to be the relative SES of subregions, rather than absolute SES, prevalence of health outcomes, or health inequalities. To reduce the inequitable impacts of bounded rationality, policymakers can use simple predictive models to target CCT coverage effectively and without leaving behind the most vulnerable populations that happen to live in more affluent subregions.
\end{abstract}

Keywords: Program Targeting, Conditional Cash Transfer, Normative Frames, Health Equity, Socioeconomic Status, Bolivia, Colombia, Ecuador, Peru

\footnotetext{
Correspondence: matp33@yorku.ca

'School of Global Health, Faculty of Health, York University, 4700 Keele

Street, Dahdaleh Building 5022C, Toronto, Ontario M3J 1P3, Canada

${ }^{2}$ Global Strategy Lab, York University, 4700 Keele Street, Dahdaleh Building

5022C, Toronto, Ontario M3J 1P3, Canada
}

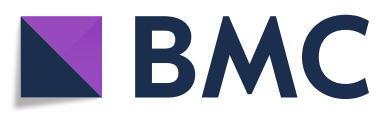

(c) The Author(s). 2020 Open Access This article is licensed under a Creative Commons Attribution 4.0 International License, which permits use, sharing, adaptation, distribution and reproduction in any medium or format, as long as you give appropriate credit to the original author(s) and the source, provide a link to the Creative Commons licence, and indicate if changes were made. The images or other third party material in this article are included in the article's Creative Commons licence, unless indicated otherwise in a credit line to the material. If material is not included in the article's Creative Commons licence and your intended use is not permitted by statutory regulation or exceeds the permitted use, you will need to obtain permission directly from the copyright holder. To view a copy of this licence, visit http://creativecommons.org/licenses/by/4.0/ The Creative Commons Public Domain Dedication waiver (http://creativecommons.org/publicdomain/zero/1.0/) applies to the data made available in this article, unless otherwise stated in a credit line to the data. 


\section{Background}

Policymakers face difficult choices when designing and implementing policies meant to address health inequalities. The way policymakers perceive determinants of health and cope with information gaps at the time of decision-making can have a large effect on the impacts these policies will have. While these inner thought processes (i.e. normative frames), [1-3] the consequences of making decisions with less than perfect information (i.e. bounded rationality), $[1,4]$ and hidden motivations (e.g. clientelism) $[5,6]$ can never be known with certainty, it is possible to probe the potential impacts of these effects with careful study of illustrative cases. Operating under the assumption that distinct policy choices made under similar conditions provide insights into the real-world consequences of these cognitive frames, this study probes four national health-focused conditional cash transfer (CCT) programs to investigate the degree to which each country's program targeting differed from both hypothetically perfect and evidence-informed counterfactuals.

Among policies meant to improve health equity, CCTs are unique in attempting to address both socioeconomic and health dimensions at the same time. Progressivity is often built into the targeting of CCT programs through income- or consumption-based means-testing, geographic targeting, age or gender targeting, or by combining these factors into an aggregate index [7]. Once the target population is identified, conditionalities, which could include minimum school attendance, giving birth at a health center, bringing infants to health checkups, receiving vaccinations, or attending community social outreach programs must be met as a prerequisite for receiving a cash transfer $[8,9]$. The size of cash benefits varies between countries, but are generally intended to offset opportunity costs associated with the conditional behavior [10]. Although the long-term goals of these programs, and thus, the effectiveness of reaching those goals is disputed, [11] there is evidence that these programs are achieving progress in improving health, school attendance, and social cohesion while reducing poverty with low administrative costs and rapid implementation [7, 12-18].

Decisions about how best to target CCT programs are often driven by normative framing of health and socioeconomic status (SES). In part, this is because quantifying SES is more complicated than simply asking for annual income in many low- and middle-income countries. Factors such as informal employment and large fluctuations in income from month to month have led many researchers, and in turn policymakers, to prefer household consumption or wealth indices as more reliable measures of SES [19-21]. Moreover, policymakers must weigh the relative importance of both absolute and relative inequalities measured by each of these SES measures. Similarly, population health can be measured in many ways, but can broadly be broken down into categories of process indicators like vaccination rates and births occurring in health facilities, and direct health outcomes ranging from acute to long-term conditions. Decisions made by policymakers can be affected by whether their subconscious framing of health inequality is an issue of access (poor households cannot access vaccinations for their children), or an issue of outcomes (poor children are more likely to die before the age of five).

Targeting the health promotion and cash benefits to those that would most benefit from them can be even more difficult in contexts with limited resources and information. While the link between adverse health outcomes and low SES has been demonstrated in nearly every setting in the world, the strength of association between the two can vary greatly both within and between countries [22-25]. In very low-income settings, the magnitude of health inequalities is often smaller than higher income settings, which is driven by broadly distributed ill health among the large proportion of the population that is poor in absolute terms [26, 27]. That means that even when some population-level information is known, targeting populations with ill health living in poverty with national CCT programs must balance the absolute distribution of both ill health and poverty, and cannot always rely on subnational health inequality indicators.

In an ideal world, CCT programs would be resourced to allow for full implementation in every part of the country and for every recipient to be individually assessed for need. However, when resources are limited, programs are often targeted geographically or the implementation of means-testing not fully resourced [28]. In theory, geographic targeting of programs can be efficient if there is wide variation in health and wealth between subnational regions, however, poor households in richer regions will inevitably be left behind. Passive meanstesting can be conducted by asking potential beneficiaries to self-identify and prove their eligibility, but ineffective program outreach can result in the households with the most need not receiving assistance they are entitled to [29]. Finally, it is always possible that this mistargeting is not due to chance, but driven by clientelist, electoral, financial, social, or economic factors.

This study leverages administrative and household survey data evaluating CCT programs created between 2003 and 2009 in four contiguous Andean countries to investigate the potential effects of policymakers' cognitive frames in targeting CCT programs. Health inequalities at the subnational level are measured using administrative program data and every nationally representative household health survey available since 1998 to investigate how the targeting of these programs varied between countries. Lastly, this study compares actual targeting of CCT programs in each country against both 
a hypothetical perfectly targeted model and a simple data-driven model using information available to policymakers at the time of annual program implementation. Together, these analyses probe how policymakers in these four countries frame the issue of inequalities in health and cope with missing information and limited resources.

\section{Methods}

The objective of the case selection strategy was to identify contemporaneous national CCT programs in a defined region to provide more confidence that differences in the distribution of health and SES, and not temporal or cultural factors, were driving decision making, while also including a diverse set of approaches to geographic targeting and means-testing. This diverse-case purposive sampling strategy led to the wave of Latin American CCT programs that were rolled out in the 2000s in the wake of two highly touted programs of Bolsa Familia in Brazil and Progresa in Mexico [30-32]. Within this region, four contiguous Andean countries of Colombia, Ecuador, Peru, and Bolivia were identified that had all developed health-focused CCTs within a period of 6 years, but were evenly split between strong and weak means-targeting, and geographic targeting and universal rollout. Other Andean countries were considered for inclusion, but Venezuela was lacking in reliable longitudinal data, while Argentina and Chile's relatively high SES and more complex welfare state architecture would have complicated regional comparisons [8, 33, 34]. A focus on Central American countries was also considered, but the smaller scale of these countries' CCT programs, as well as the early discontinuation or lack of explicit focus on health of some programs would have resulted in a less informative approach than a focus on the Andean region $[8,35,36]$.

The four CCT programs under study (Table 1) are united in their focus on improving maternal and child health using cash transfers conditioned on specific health-promoting co-responsibilities. Colombia's Más Familias en Acción (MFA) is a multifaceted CCT program intended to improve health and educational outcomes, targeting poor households and internally displaced victims of violence [18, 38, 39]. Ecuador revamped and expanded the Bono Solidario into the Bono de Desarrollo Humano (BDH) in 2003, incorporating CCTs to improve health and educational outcomes among poor families $[14,42]$. Peru's Juntos was created in 2005, seeking to break the intergenerational transmission of poverty by improving the health and education of children [16, 43]. Finally, Bolivia created the Bono Juana Azurduy (BJA) in 2009 to improve maternal and child health [12]. Taken together, two of the CCT programs relied on geographic targeting (MFA and Juntos) and three programs developed a quantitative instrument to target vulnerable households (MFA, BDH, and Juntos). Moderate differences in health and wealth between these four countries detailed in Table 1 are to be expected with a purposive diverse-case sampling strategy and allow for the generation of information on whether policymakers use geographic targeting and means-testing to maximize scarce resources, and whether broadly distributed ill health and lower information quality make these strategies a rational choice.

There are a total of 88 subnational regions throughout the four countries, with 9 Departments in Bolivia, 33 Departments in Colombia, 21 Provinces in Ecuador, and 25 Provinces in Peru. Although the populations of each subregion range from 30,000 to $9,000,000$, each country has a similar range of population distributions with at least one smaller subregion of approximately 100,000 inhabitants and the largest subregion containing more than 2,500,000 people. In order to measure outcome data, every subregionallyrepresentative health survey since 1998 was included for analysis. For Bolivia this included Demographic and Health Surveys (DHS) for 1998, 2003, and 2008, a Multiple Indicator Cluster Survey from 2000, and the Encuesta de Evaluación de Salud y Nutrición (ESNUT) from 2012. For Colombia, three DHS survey rounds were used from 2005, 2010, and 2015. ${ }^{1}$ The Encuesta demográfica $y$ de salud materna e infantil (ENDEMAIN) from 1999 and 2004 and the 2012 Encuesta Nacional de Salud y Nutrición (ENSANUT) were used for Ecuador. Finally, six rounds of DHS from 2000, 2004, 2009, 2010, 2011, and 2012 were available for Peru. Enrollment data at the subnational region level for each CCT program (Fig. 1) was obtained from the government agencies responsible for implementation in each country. Survey-reported CCT program enrollment was used to calculate household-level inequalities, while administrative data was used for all regression-based analyses.

Health outcomes were selected to be comparable between countries and to be relevant to the four CCT programs, which broadly cover maternal and child health. Prevalence of third dose of diphtheria, pertussis, and tetanus (DPT) or pentavalent vaccine was selected as a process indicator of public health protection for children. ${ }^{2}$ Direct health outcomes ranged from shorter term to longer term, with underweight used as an indicator of acute malnutrition, stunting as an indicator of chronic malnutrition, and ratio of child deaths to births reported by women aged $15-49$ as an indicator of mortality. ${ }^{3}$ Age-standardized weight-for-age and height-for-age $\mathrm{z}$-scores using DHS

\footnotetext{
${ }^{1}$ The 2000 Colombia DHS is not representative at subregion level.

${ }^{2}$ Births attended by skilled staff or deliveries occurring in health facilities could not be used because data are not comparable across countries and are dependent on preexisting infrastructure.

${ }^{3}$ Wasting was not included as an indicator because of low prevalence at the subregion level.
} 
Table 1 Key country and CCT program characteristics for Bolivia, Colombia, Ecuador, and Peru

\begin{tabular}{|c|c|c|c|c|c|c|c|}
\hline Country & $\begin{array}{l}\text { GDP per } \\
\text { capita, PPP [33] }\end{array}$ & $\begin{array}{l}\text { Infant } \\
\text { Mortality } \\
\text { Rate [33] }\end{array}$ & $\begin{array}{l}C C T \\
\text { Program } \\
\text { (year launched) }^{\mathbf{a}}\end{array}$ & CCT Focus & $\begin{array}{l}\text { Targeting } \\
\text { mechanism }\end{array}$ & Target population & $\begin{array}{l}\text { Program } \\
\text { enrollment } \\
\text { (budget in \$US) }\end{array}$ \\
\hline Bolivia & $\$ 7081$ & 29.2 & $\begin{array}{l}\text { Bono Juana } \\
\text { Azurduy (2009) }\end{array}$ & Health & $\begin{array}{l}\text { Universal, weak } \\
\text { means-testing }\end{array}$ & $\begin{array}{l}\text { All pregnant women } \\
\text { who report not } \\
\text { having social protection } \\
\text { coverage [37] }\end{array}$ & $\begin{array}{l}127 \text { thousand } \\
\text { beneficiaries } \\
(\$ 33 \text { million })^{b}[12]\end{array}$ \\
\hline Colombia & $\$ 12,982$ & 14.9 & $\begin{array}{l}\text { Más Familias } \\
\text { en Acción (2006) }\end{array}$ & $\begin{array}{l}\text { Health and } \\
\text { education }\end{array}$ & $\begin{array}{l}\text { Geographic, weak } \\
\text { means-testing }\end{array}$ & $\begin{array}{l}\text { SISBEN household } \\
\text { vulnerability index } \\
\text { based on health, } \\
\text { education, household, } \\
\text { and vulnerability } \\
\text { indicators and residence } \\
\text { in specified municipal } \\
\text { groups }[18,38,39]\end{array}$ & $\begin{array}{l}2.7 \text { million families } \\
(\$ 1149 \text { million })^{c}[38]\end{array}$ \\
\hline Ecuador & $\$ 11,431$ & 14.4 & $\begin{array}{l}\text { Bono de } \\
\text { Desarrollo } \\
\text { Humano (2003) }\end{array}$ & $\begin{array}{l}\text { Health and } \\
\text { education }\end{array}$ & $\begin{array}{l}\text { Universal, strong } \\
\text { means-testing }\end{array}$ & $\begin{array}{l}\text { Selben index based on } \\
\text { infrastructure, } \\
\text { demographics, education, } \\
\text { and household } \\
\text { assets [13] }\end{array}$ & $\begin{array}{l}1.2 \text { million } \\
\text { beneficiaries } \\
(\$ 481 \text { million })^{d}[40]\end{array}$ \\
\hline Peru & $\$ 11,176$ & 14.3 & Juntos (2005) & $\begin{array}{l}\text { Health and } \\
\text { education }\end{array}$ & $\begin{array}{l}\text { Geographic, strong } \\
\text { means-testing }\end{array}$ & $\begin{array}{l}\text { Several iterations } \\
\text { of district } \\
\text { and household } \\
\text { level indices based on } \\
\text { health, education, } \\
\text { demographic, and wealth } \\
\text { indicators }[17,41]\end{array}$ & $\begin{array}{l}650 \text { thousand } \\
\text { households } \\
(\$ 324 \text { million })^{\mathrm{e}}[17,41]\end{array}$ \\
\hline
\end{tabular}

a Although Colombia's MFA was originally created in 2000, it was massively expanded and revamped in 2006. Ecuador's BDH represents a significant expansion in budget and scope of the Bono Solidario, originally created in 1998.

b Bolivia data are for 2013

c Colombia data are for 2014

d Ecuador data are for 2012

e Peru data are for 2012

standards based on WHO Anthro definitions were used to calculate prevalence of underweight and stunting [44, 45]. Finally, household wealth indices were calculated for nonDHS household surveys using the standard DHS principal components analysis method [46-48].

The first analyses were conducted to break down inequalities in health outcomes and CCT targeting according to the proportions explained by household SES and geography. In order to do this, the proportion of inequalities in vaccine coverage, underweight, stunting, and child deaths attributable to residence in a geographic subregion and to household SES quintile was decomposed using a generalized entropy index $[49,50]$. Generalized entropy indices are information theoretic measures of inequality that have the useful property of additive decomposability, meaning that the sum of within-group and between-group inequality is equal to total inequality [51]. Therefore, it is not the generalized index value itself that is of interest (because it is purely a function of prevalence), but the percentage that is additively decomposed to within- and between-subregion and to within- and between-SES quintile components [51, 52]. As a separate measure of SES-related health and CCT coverage inequalities, concentration indices (CIs) were calculated for each outcome [53, 54]. CIs are bivariate measures of inequality which can be conceptualized as being equal to the value of two times the area between a concentration curve and the line of equality; or the proportion of the outcome that would have to be redistributed from the richest half to the poorest half of the population [54, 55]. Key to this analysis is that in order for a CCT program to be sufficiently progressive to reach all of those in need, the CCT coverage CI must be at least as large as the health outcome CI. In other words, a larger CI for the health outcome than the CCT coverage would mean that even if the program was perfectly targeted to only households in relative poverty that had the health outcome of interest, there would still be poor households with the health outcome that lacked coverage.

In order to investigate plausible cognitive frames underlying policymaker's decision making in targeting CCT coverage, one-year lagged subregion SES, one-year lagged subregion health outcomes, and one-year lagged subregion health outcome CIs were used as independent variables to predict subregion-specific CCT program enrollment data. All independent variables were lagged to model information that might have been available to policymakers and bureaucrats at the time of decision making for targeting the following year's program. ${ }^{4}$ Subregion SES was measured in two ways to account for

${ }^{4}$ Each regression was run separately for children's and women's CCT coverage. 


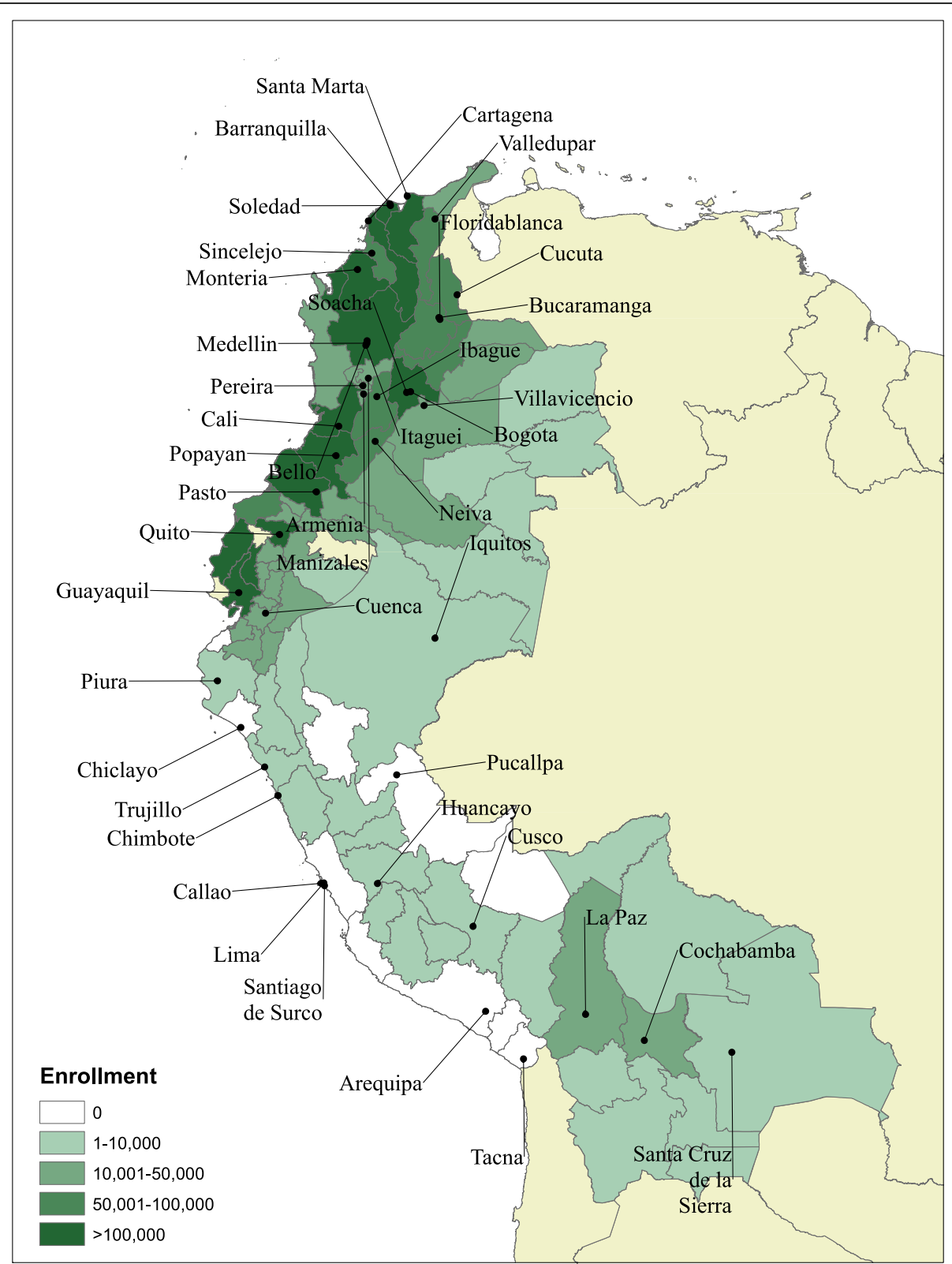

Fig. 1 Number of adult CCT enrollees per subregion for Bolivia, Colombia, Ecuador, and Peru

different frames of relative poverty - the prevalence of households in the poorest national SES quintile (absolute poverty) and the subregion's national rank of prevalence of households in poorest SES quintile (relative poverty). Each of these variables lead to different explanatory mechanisms. If targeting the poorest populations is the primary objective, one would expect significantly higher CCT coverage in poor subregions. If targeting the sickest populations is the primary objective, one would expect significantly higher CCT coverage in subregions with worse health outcomes. Finally, the possibility that highly concentrated populations living in poverty with poor health could have given additional salience to the urgency of addressing inequalities in that subregion led to the inclusion of the CI of health inequalities as an explanatory variable.

Lastly, two predictive models were created to simulate what would have happened if policymakers had either (1) perfect information and direct control over CCT targeting (2) reasonable predictions based on information that would be available to them at the time of decision making and direct control over CCT targeting. To simulate the first counterfactual, country-specific CCT coverage was apportioned by subregion according to its share of vaccine coverage, underweight, stunting, and child deaths. To simulate the second counterfactual, a simple 
linear prediction based on regression of one-year lagged subregion SES rank and subregion prevalence of children and women in the poorest national SES quintile with each outcome was used to apportion countryspecific CCT coverage. Both predictions do not change the number of persons enrolled in CCT programs, but rather redistribute enrollment according to each outcome and prediction method. The gap between both perfect and data-based prediction and the actual CCT program distribution was then evaluated for differences, which may be due to mistargeting or the result of some other decision-making factor.

\section{Results}

Decompositions of generalized entropy index values into components that are explained by between-subregion components and between-SES quintile components
(Table 2) reveal a generally decreasing trend in both components over time. Although this study was not designed to evaluate this trend, it appears possible that both types of inequalities have decreased at a faster rate after the introduction of CCT programs. Inequalities attributable to SES quintiles are generally larger than between-subregion inequality for most health outcomes and years, but between-subregion inequalities are always larger for vaccine coverage. Peru displays the largest between-SES quintile and between-subregion inequality for almost every measure, except for inequalities in vaccine coverage in Ecuador and SES-related inequalities in child deaths in Bolivia. In sum, both geographic and SES-related inequalities are important factors, but the relative importance varies by health outcome and country.

In comparison to pure inequality decomposed into constituent parts, SES-related inequalities in health

Table 2 Proportion of generalized entropy index decomposed between region (left) and between SES quintile (right) components. The higher the percentage, the greater the proportion of overall inequality that can be attributed to inequality across subregions or inequality across SES quintiles. Additional space between years indicates the point at which each country's CCT program was first implemented.

\begin{tabular}{|c|c|c|c|c|c|c|c|c|}
\hline \multicolumn{5}{|c|}{ Subregional Inequality } & \multicolumn{4}{|c|}{ SES Inequality } \\
\hline & DPT & Underweight & Stunting & Child Deaths & DPT & Underweight & Stunting & Child Deaths \\
\hline \multicolumn{9}{|l|}{ Bolivia } \\
\hline 1998 & $2.13 \%$ & $1.07 \%$ & $3.24 \%$ & $1.09 \%$ & - & - & - & - \\
\hline 2000 & - & - & - & $2.30 \%$ & - & - & - & $4.15 \%$ \\
\hline 2003 & $2.24 \%$ & $1.24 \%$ & $4.13 \%$ & $1.29 \%$ & $1.22 \%$ & $2.80 \%$ & $8.19 \%$ & $3.66 \%$ \\
\hline 2008 & $1.09 \%$ & $1.67 \%$ & $5.09 \%$ & $1.83 \%$ & $0.13 \%$ & $2.34 \%$ & $9.14 \%$ & $3.30 \%$ \\
\hline 2012 & - & $0.41 \%$ & $2.12 \%$ & - & - & $1.14 \%$ & $4.24 \%$ & - \\
\hline \multicolumn{9}{|c|}{ Colombia } \\
\hline 2005 & $2.55 \%$ & $1.13 \%$ & $1.74 \%$ & $0.43 \%$ & $1.83 \%$ & $1.42 \%$ & $3.20 \%$ & $0.72 \%$ \\
\hline 2010 & $0.85 \%$ & $0.92 \%$ & $1.54 \%$ & $0.32 \%$ & $0.50 \%$ & $1.10 \%$ & $1.77 \%$ & $0.39 \%$ \\
\hline 2015 & - & - & - & $0.34 \%$ & - & - & - & $0.46 \%$ \\
\hline \multicolumn{9}{|l|}{ Ecuador } \\
\hline 1999 & $15.70 \%$ & - & - & $1.25 \%$ & $2.37 \%$ & - & - & $2.02 \%$ \\
\hline 2004 & $10.79 \%$ & $0.98 \%$ & $4.46 \%$ & $0.62 \%$ & $1.13 \%$ & $1.02 \%$ & $3.49 \%$ & $0.67 \%$ \\
\hline 2012 & - & $0.38 \%$ & $2.82 \%$ & $0.49 \%$ & - & $0.79 \%$ & $3.99 \%$ & $0.71 \%$ \\
\hline \multicolumn{9}{|l|}{ Peru } \\
\hline 2000 & $2.33 \%$ & $3.96 \%$ & $9.43 \%$ & $3.34 \%$ & - & - & - & - \\
\hline 2004 & $0.92 \%$ & $2.52 \%$ & $7.46 \%$ & $2.00 \%$ & $0.59 \%$ & $3.48 \%$ & $12.32 \%$ & $2.50 \%$ \\
\hline 2009 & $0.84 \%$ & $3.35 \%$ & $7.67 \%$ & $1.88 \%$ & $0.72 \%$ & $4.25 \%$ & $11.77 \%$ & $2.14 \%$ \\
\hline 2010 & $1.50 \%$ & $3.43 \%$ & $6.91 \%$ & $1.39 \%$ & $0.20 \%$ & $3.75 \%$ & $10.42 \%$ & $1.90 \%$ \\
\hline 2011 & $1.31 \%$ & $3.41 \%$ & $7.88 \%$ & $2.38 \%$ & $0.50 \%$ & $5.08 \%$ & $12.77 \%$ & $2.14 \%$ \\
\hline 2012 & $0.64 \%$ & $1.79 \%$ & $5.66 \%$ & $1.85 \%$ & $0.28 \%$ & $2.68 \%$ & $9.15 \%$ & $1.68 \%$ \\
\hline
\end{tabular}


Table 3 Concentration indices for each health outcome and CCT coverage $\mathrm{Cl}$ for each country-year available. Additional space between years indicates the point at which each country's CCT program was first implemented

\begin{tabular}{|c|c|c|c|c|c|}
\hline & DPT & Underweight & Stunting & Child Deaths & CCT Coverage \\
\hline \multicolumn{6}{|l|}{ Bolivia } \\
\hline 1998 & - & - & - & - & \\
\hline 2000 & - & - & - & -0.28 & \\
\hline 2003 & 0.11 & -0.37 & -0.38 & -0.24 & \\
\hline 2008 & 0.03 & -0.37 & -0.43 & -0.25 & \\
\hline 2012 & - & -0.26 & -0.30 & - & -0.07 \\
\hline \multicolumn{6}{|c|}{ Colombia } \\
\hline 2005 & 0.17 & -0.28 & -0.33 & -0.20 & \\
\hline 2010 & 0.08 & -0.27 & -0.24 & -0.15 & -0.34 \\
\hline 2015 & - & - & - & -0.19 & - \\
\hline \multicolumn{6}{|l|}{ Ecuador } \\
\hline 1999 & -0.19 & - & - & -0.24 & \\
\hline 2004 & 0.09 & -0.19 & -0.25 & -0.14 & -0.40 \\
\hline 2012 & - & -0.19 & -0.26 & -0.20 & -0.54 \\
\hline \multicolumn{6}{|l|}{ Peru } \\
\hline 2000 & - & - & - & - & \\
\hline 2004 & 0.10 & -0.45 & -0.49 & -0.27 & \\
\hline 2009 & 0.09 & -0.50 & -0.50 & -0.28 & -0.65 \\
\hline 2010 & 0.04 & -0.45 & -0.49 & -0.27 & -0.63 \\
\hline 2011 & 0.08 & -0.53 & -0.56 & -0.28 & -0.72 \\
\hline 2012 & 0.05 & -0.41 & -0.51 & -0.26 & -0.71 \\
\hline
\end{tabular}

measured by the bivariate $\mathrm{CI}$ are more stable over time (Table 3). Inequalities are generally largest for the outcomes of stunting and underweight, and there is a pro-high SES distribution of DPT vaccine coverage in every survey year except for 1999 in Ecuador. Peru consistently displays the largest SES-related inequalities in health for every outcome, but also has the most progressively means-targeted (pro-low SES) distribution of CCT coverage. Importantly, Colombia, Ecuador, and Peru have CCT coverage CIs that are larger than the health inequalities they are targeting, leaving Bolivia as the only country that could not reach sufficient progressivity even with hypothetically perfect targeting.

Targeting of subregions by health status varied greatly by outcome and country (Additional file 1: Tables 1-14). Subregions with better vaccine coverage were targeted at the same (in Colombia and Ecuador) or higher (in Bolivia and Peru) rates than other subregions, although this is partially attenuated by the omitted association with poorer subregions. Underweight and stunting were targeted at very similar rates, with higher prevalence subregions receiving higher CCT enrollment in Bolivia and Peru, but not Ecuador and Colombia. Accounting for the association of stunting and underweight with SES reduces the strength of association of targeting for Peru, but not for Bolivia. Similarly, subregions with higher prevalence of child deaths are targeted at higher rates than other subregions in Bolivia and Peru, but not Ecuador and Colombia. Bolivia is the best targeted program for child death prevalence with Peru a close second, while association with poorer subregions generally attenuates this effect for Peru, but not for children's CCT coverage in Bolivia.

Regression of country- and subregion-specific CCT enrollment data indicates that the relative SES ranking of a subregion within a country may be guiding policymakers more than the absolute prevalence of poverty in a subregion. While there was a significant association of CCT coverage with the prevalence of women and children in the poorest national quintile of household wealth in Ecuador and Peru, Table 4 demonstrates that significant association with subregion SES ranking was present in every regression iteration except among children in Colombia. ${ }^{5}$ Bolivia is the only country that systematically targeted subregions with higher prevalence of health outcomes of interest more often than those with lower absolute or relative SES. In contrast, Ecuador and Peru targeted subregions with lower relative and absolute SES at higher rates, while Colombia did not appear to systematically target subregions based on health outcome prevalence, poverty, or inequality. Targeting was also fairly consistent between health outcomes, with only vaccination displaying different patterns of association in Bolivia and Peru.

Comparing actual CCT targeting against a redistributed CCT targeting model using perfect knowledge (Fig. 2) indicates that Peru had the highest rate of mistargeting for every outcome driven by the many subregions with no CCT enrollees. Bolivia appears to have the lowest rates of mistargeting, although there are fewer data points with which to measure this efficiency (Additional file 1: Table 15). Among countries with several data points, Colombia and Ecuador have the lowest rates of mistargeting for child deaths, while Peru has the lowest rates of mistargeting for stunting. In Bolivia, Tarija is the most over-targeted subregion, and Pando the most under-targeted. In Colombia, Caldas, Cauca, Huila, Sucre, and Tolima are among the most over-targeted subregions, and Bogotá, Córdoba, La Guajira, Vaupés, and Vichada the most under-targeted. In Ecuador, Guayas, El Oro, and Manabí are among the most over-targeted subregions, and Cañar, Galápagos, and Pichincha the most under-targeted. Finally,

${ }_{5}^{5}$ Full regressions for every country, coverage population, and SES measure available in Appendix Tables 1-14 
Table 4 Regression results for targeting of CCT programs among women and children in Bolivia, Colombia, Ecuador, and Peru. SES rank represents each subregion's relative rank from richest to poorest in the country, prevalence is specific to each health outcome (underweight, stunting, DPT vaccine coverage, and child deaths), and inequality is measured by the concentration index for each health outcome

\begin{tabular}{|c|c|c|c|c|c|c|c|c|c|}
\hline & & \multicolumn{4}{|c|}{ Women's coverage } & \multicolumn{4}{|c|}{ Children's coverage } \\
\hline & & Under-weight & Stunting & DPT & Child Deaths & Under-weight & Stunting & DPT & Child Deaths \\
\hline \multirow[t]{10}{*}{ Bolivia } & Prevalence & $0.344^{* * *}$ & 0.0576 & 0.0773 & 0.123 & $1.868^{* * *}$ & $0.447^{* * *}$ & -0.121 & $1.006^{* *}$ \\
\hline & & $(0.0970)$ & $(0.0460)$ & $(0.0545)$ & $(0.114)$ & $(0.142)$ & $(0.0754)$ & $(0.242)$ & $(0.412)$ \\
\hline & SES Rank & 0.000528 & 0.00171 & $0.00426^{* * *}$ & $0.00437^{* * * *}$ & -0.00442 & -0.000325 & $0.0161^{* *}$ & $0.0101^{*}$ \\
\hline & & $(0.00109)$ & $(0.00133)$ & $(0.00115)$ & $(0.000663)$ & $(0.00411)$ & (0.00318) & $(0.00635)$ & $(0.00474)$ \\
\hline & Inequality & -0.00656 & 0.00259 & $0.0333^{* *}$ & 0.00886 & -0.0112 & 0.00116 & -0.115 & -0.102 \\
\hline & & $(0.0112)$ & $(0.0153)$ & $(0.0133)$ & $(0.0346)$ & $(0.0235)$ & $(0.0514)$ & $(0.183)$ & $(0.156)$ \\
\hline & Constant & $0.0199^{* *}$ & $0.0215^{* *}$ & -0.0342 & $0.0204^{*}$ & $0.0817^{* *}$ & $0.0652^{* *}$ & 0.206 & 0.0444 \\
\hline & & $(0.00659)$ & $(0.00728)$ & $(0.0410)$ & $(0.00980)$ & $(0.0249)$ & $(0.0257)$ & $(0.169)$ & $(0.0418)$ \\
\hline & Obs. & 18 & 18 & 9 & 9 & 18 & 18 & 9 & 9 \\
\hline & R-squared & 0.568 & 0.359 & 0.877 & 0.843 & 0.753 & 0.490 & 0.590 & 0.720 \\
\hline \multirow[t]{10}{*}{ Colombia } & Prevalence & 0.534 & -0.858 & 0.262 & -1.918 & 0.583 & -1.326 & 0.256 & -2.541 \\
\hline & & $(0.966)$ & $(0.594)$ & $(0.457)$ & $(1.403)$ & (1.513) & $(0.900)$ & $(0.731)$ & (2.110) \\
\hline & SES Rank & 0.00209 & $0.00559^{* *}$ & $0.00541^{*}$ & $0.00532^{* *}$ & -0.000488 & 0.00422 & 0.00392 & 0.00462 \\
\hline & & $(0.00270)$ & $(0.00270)$ & $(0.00267)$ & $(0.00207)$ & $(0.00408)$ & $(0.00400)$ & $(0.00400)$ & $(0.00298)$ \\
\hline & Inequality & 0.0914 & 0.0459 & -0.333 & -0.0214 & 0.0366 & -0.0996 & -0.488 & -0.0164 \\
\hline & & $(0.127)$ & $(0.191)$ & $(0.230)$ & $(0.118)$ & $(0.195)$ & $(0.301)$ & $(0.366)$ & $(0.162)$ \\
\hline & Constant & $0.192^{* * *}$ & $0.239^{* * *}$ & -0.0346 & $0.198^{* * *}$ & $0.342^{* * *}$ & $0.395^{* * *}$ & 0.131 & $0.320^{* * *}$ \\
\hline & & $(0.0469)$ & $(0.0460)$ & $(0.378)$ & $(0.0434)$ & $(0.0671)$ & $(0.0689)$ & $(0.609)$ & $(0.0607)$ \\
\hline & Obs. & 33 & 33 & 33 & 66 & 33 & 33 & 33 & 66 \\
\hline & R-squared & 0.084 & 0.173 & 0.125 & 0.163 & 0.007 & 0.103 & 0.065 & 0.064 \\
\hline \multirow[t]{10}{*}{ Ecuador $^{\mathrm{a}}$} & Prevalence & -0.0941 & 0.0126 & 0.147 & 0.598 & - & - & - & - \\
\hline & & $(0.315)$ & $(0.156)$ & $(0.136)$ & $(0.904)$ & - & - & - & - \\
\hline & SES Rank & $0.0131^{* * *}$ & $0.0124^{* * *}$ & $0.0109^{* * *}$ & $0.0128^{* * *}$ & - & - & - & - \\
\hline & & (0.00318) & $(0.00243)$ & $(0.00317)$ & $(0.00238)$ & - & - & - & - \\
\hline & Inequality & 0.0242 & -0.0974 & 0.0548 & 0.118 & - & - & - & - \\
\hline & & $(0.0825)$ & $(0.143)$ & $(0.0946)$ & $(0.0735)$ & - & - & - & - \\
\hline & Constant & $0.165^{* * *}$ & $0.134^{*}$ & 0.0444 & $0.152^{* * *}$ & - & - & - & - \\
\hline & & $(0.0382)$ & $(0.0690)$ & $(0.0935)$ & $(0.0520)$ & - & - & - & - \\
\hline & Obs. & 40 & 42 & 21 & 42 & - & - & - & - \\
\hline & R-squared & 0.511 & 0.521 & 0.506 & 0.556 & - & - & - & - \\
\hline \multirow[t]{10}{*}{ Peru } & Prevalence & 0.00353 & 0.00582 & $0.0112^{* * *}$ & -0.0177 & -0.117 & 0.0936 & $0.152^{* * *}$ & -0.383 \\
\hline & & $(0.0120)$ & $(0.00409)$ & $(0.00355)$ & $(0.0231)$ & $(0.171)$ & $(0.0806)$ & $(0.0452)$ & $(0.284)$ \\
\hline & SES Rank & $0.000313^{* * *}$ & $0.000257^{* * *}$ & $0.000316^{* * *}$ & $0.000345^{* * *}$ & $0.00710^{* * *}$ & $0.00539^{* * *}$ & $0.00634^{* * *}$ & $0.00696^{* * *}$ \\
\hline & & $(5.69 \mathrm{e}-05)$ & $(5.81 e-05)$ & $(2.91 \mathrm{e}-05)$ & $(3.73 e-05)$ & $(0.000866)$ & $(0.00126)$ & $(0.000495)$ & $(0.000514)$ \\
\hline & Inequality & -0.00106 & -0.000407 & 0.000488 & -0.00217 & $-0.0259^{*}$ & -0.0143 & 0.00127 & -0.0499 \\
\hline & & $(0.000837)$ & $(0.00116)$ & $(0.00314)$ & $(0.00203)$ & $(0.0144)$ & $(0.0194)$ & $(0.0415)$ & $(0.0397)$ \\
\hline & Constant & $-0.00215^{* * *}$ & $-0.00205^{* * *}$ & $-0.00924^{* * *}$ & $-0.00164^{*}$ & $-0.0428^{* * *}$ & $-0.0419^{* * *}$ & $-0.138^{* * *}$ & $-0.0340^{* *}$ \\
\hline & & $(0.000516)$ & $(0.000493)$ & $(0.00255)$ & $(0.000809)$ & $(0.00891)$ & $(0.00937)$ & $(0.0330)$ & $(0.0148)$ \\
\hline & Obs. & 92 & 96 & 96 & 100 & 69 & 72 & 72 & 75 \\
\hline & R-squared & 0.527 & 0.545 & 0.588 & 0.550 & 0.701 & 0.709 & 0.733 & 0.719 \\
\hline
\end{tabular}




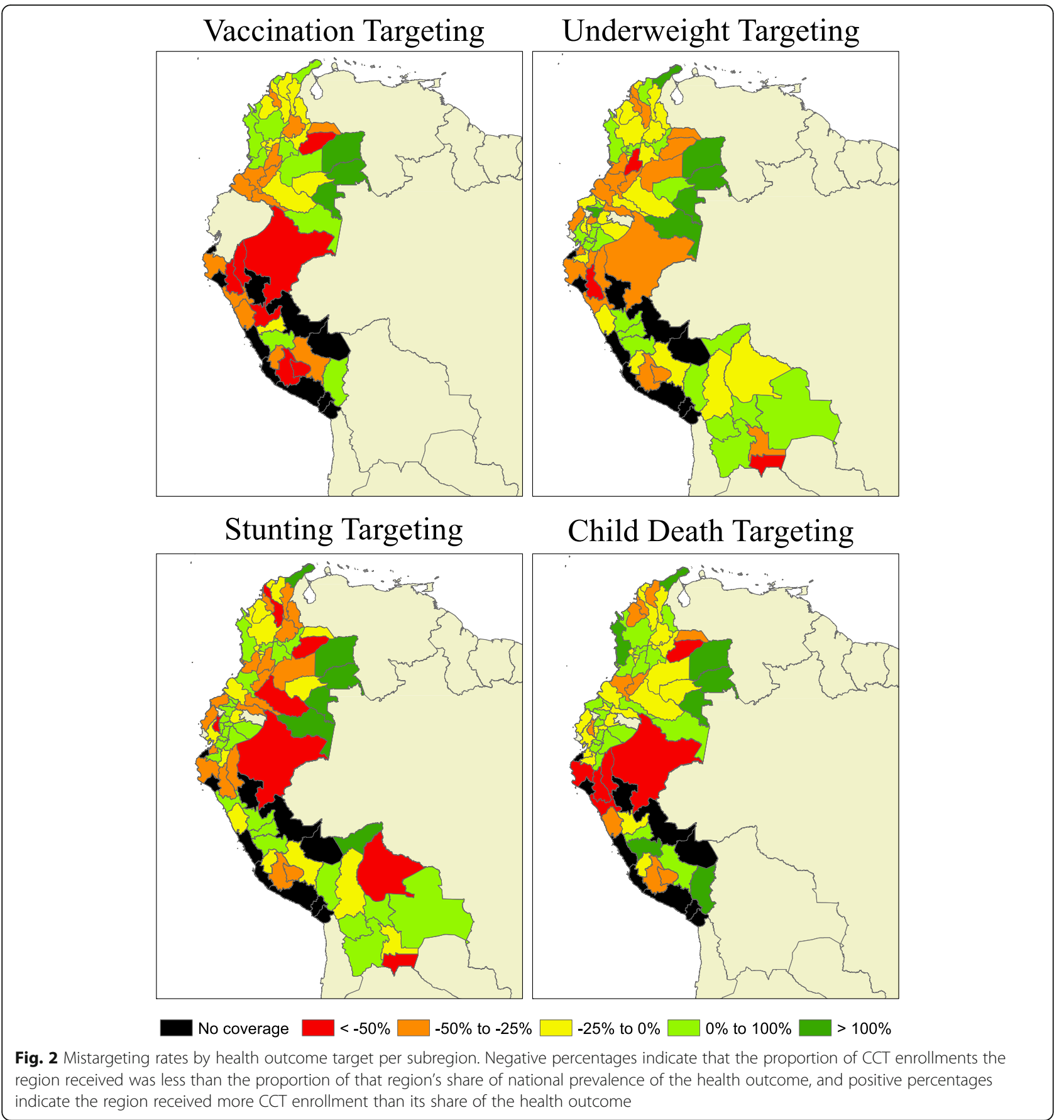

in Peru, Áncash, Apurímac, Ayacucho, Huánuco, and Piura are among the most over-targeted subregions, and Lambayeque, Lima, San Martín, and Ucayali the most under-targeted.

The simple predictive model constructed using information available to policymakers at the time of implementation performs as well or better than the observed CCT enrollment distribution for every country, year, and outcome. While the actual CCT distribution for Bolivia is about as well targeted as the simple predictive model,
Colombia and Ecuador would reduce their mistargeting by as much as half, and Peru would reduce its mistargeting by $50-75 \%$ if the simple predictive model was used.

\section{Discussion}

The degree to which health focused CCT programs have successfully targeted the populations and health outcomes they are intended to address has yet to be quantitively 
evaluated using multi-country data. The underlying logic of these programs - that socioeconomic inequality and poverty is a critical determinant of health - is supported by this study's results. Household SES was found to be a more important driver of malnutrition and mortality than geography in every country and year, regardless of the magnitude of SES-related inequalities in health. Although between-subregion inequalities in vaccine coverage are larger than SES-related inequalities, targeting by SES still greatly outperforms any subregional targeting currently used in these countries.

Using efficiency in targeting populations in need of CCT programs as an evaluation metric, universal rollout of CCT programs appears to outperform geographic targeting. Although Bolivia and Peru both targeted at-risk subregions at significantly higher rates than other subregions, subregions in Peru with no coverage result in much less efficient targeting for the country as a whole. Ecuador targets low SES populations more effectively than Colombia while maintaining universal protection, although both are mistargeting vaccine coverage, childhood malnutrition, and mortality at about the same moderate rate. Finally, and contrary to hypotheses of self-dealing by national governments through the administration of CCT programs, capital subregions were systematically under targeted in three of the four countries.

With regard to the normative frames employed by policymakers, this study provides evidence that SES and relative rather than absolute SES - may be the dominant normative frame at work in the design of CCT program targeting. Bolivia was the sole country that appeared to target more on the basis of health outcome prevalence than on SES, which may be a direct product of policymakers' decision to apply a weak proxy-means test rather than multidimensional household SES indicators, as other countries have done. Similarly, the higher proportion of variation in targeting explained in regression models for the process indicator of vaccine coverage than for outcome indicators of underweight and stunting may indicate that policymakers' normative frames of access to health are outweighing those of direct health outcomes.

This study's results are broadly consistent with previous studies of equity in targeting CCT programs in the Andean region. The relative lack of progressivity in Bolivia's

\footnotetext{
${ }^{6}$ Author's own calculations from Table 2. Cobertura del programa Familias en Acción a nivel de hogar por nivel de ingreso y zona in Elisa Flórez C, Rodríguez K. Subsidios sociales, pobreza y desigualdad. Departamento Nacional de Planeación; 2016 Dec p. 16-33. (Observatorio de Familia). Report No.: 8.

${ }^{7}$ Author's own calculations from Table 3. Distribution of Beneficiaries by Income Decile in Amarante V, Brun M. Cash Transfers in Latin America: Effects on Poverty and Redistribution. Economía. 2018;19(1):1-31.
}

BJA targeting is supported by previous findings that although program targeting is progressive in absolute terms, over half of the program's resources go to non-poor households $[12,56]$. Colombia's MFA program coverage was measured to have a CI of -0.44 in 2012, a moderately higher estimate of SES-related inequality than this study's findings, which may be due to different survey year and data source. ${ }^{6}$ [57] Finally, an analysis of progressivity of Latin American CCT programs using 2013 economic household survey data imply program coverage CIs of 0.46 for Ecuador's BDH and - 0.71 for Peru's Juntos - estimates that are nearly identical to this study's results. ${ }^{7}$ [58]

Although this study represents one of the most comprehensive multi-country analyses of CCT targeting to date, it did not investigate the effects of absolute CCT program coverage rates, which are significantly higher in Colombia and Ecuador. Relatedly, government agencies responsible for vaccination programs may have specifically targeted subregions known to be vulnerable to adverse childhood health outcomes, leading to issues of endemicity. The study is also limited by country-specific differences in objectives and priorities for CCT program targeting. Some countries may place more emphasis on process and access (e.g. vaccinations) and others on direct health outcomes (i.e. child mortality). Furthermore, publicly stated CCT program objectives may obscure underlying clientelist, budgetary, or logistical factors affecting program delivery. While some of these limitations can be addressed by further qualitative study, this initial quantitative evidence of the cognitive frames used by policymakers in four Andean countries provides a starting point for further study.

Two key policy implications can be reached from this analysis of targeting of CCT programs in Colombia, Ecuador, Peru, and Bolivia. First, geographic targeting may be a low-cost method of rationing scarce resources, but it is not a replacement for means-testing if CCT programs are meant to be targeted to populations with the highest levels of ill health. In fact, even a simple predictive model based on subregion-specific SES performs much better at targeting at-risk populations than any current method being used by each of these countries. Second, every CCT program in this study has achieved progressivity in targeting and are therefore successfully promoting greater health equity. Importantly, both Peru and Ecuador have targeted programs to their poorest populations effectively, demonstrating that this is possible with both universal and geographic targeting approaches. Finally, if solidarity with the poorest and sickest populations in a country is the fundamental feature of CCT programs, excluding the most vulnerable women and children that happen to live in more affluent subregions directly undermines that goal. 


\section{Supplementary information}

Supplementary information accompanies this paper at https://doi.org/10. 1186/s12939-020-01233-0.

\section{Additional file 1}

\section{Abbreviations}

BDH: Bono de Desarrollo Humano; BJA: Bono Juana Azurduy; CCT: Conditional Cash Transfer; Cl: Concentration index; DPT: Diphtheria, pertussis, and tetanus; DHS: Demographic and Health Survey; ENDEMA IN: Encuesta demográfica y de salud materna e infantil; ENSANUT: Encuesta Nacional de Salud y Nutrición; ESNUT: Encuesta de Evaluación de Salud y Nutrición; MFA: Más Familias en Acción; SES: Socioeconomic status

\section{Acknowledgements}

I gratefully acknowledge Dr. Michel Grignon, Dr. Karen Grépin, and Dr. Michelle Dion for their feedback on the framing and methodological approaches that would most effectively address this research question.

\section{Author's contributions}

MJPP conceived of the study, collected data, conducted data analysis, interpreted the data, and wrote the manuscript. The author(s) read and approved the final manuscript.

\section{Funding}

There was no source of funding for this research.

\section{Availability of data and materials}

All datasets analyzed are publicly available for download through the DHS Program (https://dhsprogram.com/data/available-datasets.cfm), the Unidad de Análisis de Políticas Sociales y Económicas (http://www.udape.gob.bo/ index.php?option=com_wrapper\&view=wrapper\&ltemid=137), Global Health Data Exchange (http://ghdx.healthdata.org/record/ecuador-reproductivehealth-survey-2004), the Ministerio de Salud Pública (https://www.salud.gob. ec/encuesta-nacional-de-salud-y-nutricion-ensanut/), and UNICEF (http://mics. unicef.org/surveys).

\section{Ethics approval and consent to participate}

This study used only publicly available secondary and administrative data and was therefore exempt from review by an ethics review board.

\section{Consent for publication}

Not applicable.

\section{Competing interests}

The author declares that they have no competing interests.

Received: 30 October 2019 Accepted: 30 June 2020

Published online: 31 July 2020

\section{References}

1. Campbell JL. Ideas, Politics, and Public Policy. Annu Rev Sociol. 2002 Aug; 28(1):21-38

2. Bloemraad I, Kymlicka W, Lamont M, Hing LSS. Membership without Socia Citizenship? Deservingness \& Redistribution as Grounds for Equality. Daedalus. 2019; 148(3):73-104. https:/www.mitpressjournals.org/doi/full/10.1162/daed_a_01751.

3. Surel $Y$. The role of cognitive and normative frames in policy-making. J Eur Public Policy. 2000;7(4):495-512.

4. Dolowitz DP, Marsh D. Learning from Abroad: The Role of Policy Transfer in Contemporary Policy-Making. Governance. 2000;13(1):5-23.

5. Rudra N. Welfare States in Developing Countries: Unique or Universal? J Polit. 2007:69(2):378-96.

6. Ansell A, Mitchell K. Models of Clientelism and Policy Change: The Case of Conditional Cash Transfer Programmes in Mexico and Brazil. Bull Lat Am Res. 2011;30(3):298-312.

7. Cecchini S, Madariaga A. Conditional Cash Transfer Programmes: The Recent Experience in Latin America and the Caribbean. Economic Commission for Latin America and the Caribbean, editor. Santiago, Chile: United Nations; 2011.
8. Fiszbein A, Schady NR. Conditional Cash Transfers: Reducing Present and Future Poverty. World Bank Policy Research Report. Washington DC: The International Bank for Reconstruction and Development / The World Bank; 2009.

9. Manley J, Gitter S, Slavchevska V. How Effective are Cash Transfer Programmes at Improving Nutritional Status? A Rapid Evidence Assessment of Programmes' Effects on Anthropometric Outcomes. London: EPPI-Centre, Social Science Research Unit, Institute of Education, University of London; 2012.

10. Valencia LE. Conditional Cash Transfers as Social Policy in Latin America: An Assessment of their Contributions and Limitations. Annu Rev Sociol. 2008; 34(1):475-99.

11. Valencia LE. Conditional Cash Transfer Programs : Achievements and Illusions. Glob Soc Policy. 2009;9(2):167-71.

12. Vidal Fuertes C, Martínez S, Celhay P, Claros Gómez S. Evaluación de Impacto del Programa de Salud Materno Infantil "Bono Juana Azurduy" [Internet]. Unidad de Análisis de Políticas Sociales y Económicas (UDAPE); 2015. Report No.: 4-1-1965-15. Available from: http://www.udape.gob.bo/ portales_html/docsociales/BonoJuanaAzurduy.pdf [cited 192019 Sep].

13. Gonzalez-Rozada M, Pinto FL. The Effects of a Conditional Transfer Program on the Labor Market: The Human Development Bonus in Ecuador, Department of Economics Working Papers 2011-04, Universidad Torcuato Di Tella. 2011.

14. Fernald LCH, Hidrobo M. Effect of Ecuador's cash transfer program (Bono de Desarrollo Humano) on child development in infants and toddlers: a randomized effectiveness trial. Soc Sci Med. 2011;72(9): $1437-46$.

15. Schady N. Cash transfers, conditions, school enrollment, and child work: Evidence from a randomized experiment in Ecuador. 2006. (Impact Evaluation Series No. 3).

16. Sánchez A, Rodríguez MG. Balance del impacto de JUNTOS, Programa de Transferencias Condicionadas del Perú. Ministerio de Educación; 2016.

17. Díaz JJ, Saldarriaga V. Efectos del Programa de Transferencias Condicionadas JUNTOS en el Peso al Nacer de los Niños: Informe Final. 2014;.

18. Llano J. Familias en Acción: la historia a la luz de sus impactos. Coyuntura Económica. Fedesarrollo; 2014 p. 77-120. (Investigación económica y social). Report No: XLIV.

19. Poirier MJP, Grépin KA, Grignon M. Approaches and Alternatives to the Wealth Index to Measure Socioeconomic Status Using Survey Data: A Critical Interpretive Synthesis. Soc Indic Res. 2019:12 Available from: https:// doi.org/10.1007/s11205-019-02187-9 [cited 182019 Oct].

20. Sahn DE, Stifel D. Exploring alternative measures of welfare in the absence of expenditure data. Rev Income Wealth. 2003;49(4):463-89.

21. Bollen KA, Glanville JL, Stecklov G. Economic status proxies in studies of fertility in developing countries: Does the measure matter? Popul Stud. 2002;56(1):81-96.

22. del Pilar Flores-Quispe M, Restrepo-Méndez MC, MFS M, Ferreira LZ, Wehrmeister FC. Trends in socioeconomic inequalities in stunting prevalence in Latin America and the Caribbean countries: differences between quintiles and deciles. Int J Equity Health. 2019;18(1):156.

23. Joseph G, da Silva ICM, Fink G, Barros AJD, Victora CG. Absolute income is a better predictor of coverage by skilled birth attendance than relative wealth quintiles in a multicountry analysis: Comparison of 100 low- and middleincome countries. BMC Pregnancy Childbirth. 2018;18(1).

24. Pradhan M, Sahn DE, Younger SD. Decomposing world health inequality. J Health Econ. 2003;22(2):271-93.

25. McKinnon B, Harper S, Kaufman JS, Bergevin Y. Socioeconomic inequality in neonatal mortality in countries of low and middle income: a multicountry analysis. Lancet Glob Health. 2014 Mar;2(3):e165-73.

26. Poirier MJ, Grignon M, Grépin KA, Dion ML. Transnational Wealth-Related Health Inequality Measurement. SSM. 2018:6(September):259-75.

27. Wagstaff $A$. Inequalities in health in developing countries: swimming against the tide? Policy Res Working Papers. 2002;2795:40.

28. Coburn D. Beyond the income inequality hypothesis : class, neo-liberalism, and health inequalities. Soc Sci Med. 2004:58:41-56.

29. Molyneux M, Jones WN, Samuels F. Can Cash Transfer Programmes Have 'Transformative' Effects? J Dev Stud. 2016;52(8):1087-98.

30. Sugiyama NB. The diffusion of Conditional Cash Transfer programs in the Americas. Glob Soc Policy. 2011;11(2-3):250-78.

31. Atun $R$, de Andrade LOM, Almeida G, Cotlear D, Dmytraczenko T, Frenz P, et al. Health-system reform and universal health coverage in Latin America. Lancet. 2015:385(9974):1230-47. 
32. Peck J, Theodore N. Recombinant workfare, across the Americas: Transnationalizing "fast" social policy. Geoforum. 2010;41(2):195-208.

33. The World Bank. GDP per capita, PPP (constant 2017 international \$) Bolivia, Colombia, Ecuador, Peru [Internet]. World Bank Open Data. Available from: https://data.worldbank.org/indicator/NY.GDP.PCAP.PP.KD?end=2012 \&locations=BO-CO-ECPE\&start $=2011$.

34. García J, Correa G, Rousset B. Trends in infant mortality in Venezuela between 1985 and 2016: a systematic analysis of demographic data. Lancet Glob Health. 2019;7(3):e331-6.

35. Moore C. Nicaragua's Red de Protección Social: An Exemplary but ShortLived Conditional Cash Transfer Programme [Internet]. Research Report. International Policy Centre for Inclusive Growth; 2009 Jan. (Research Report). Report No.: 17. Available from: https://ideas.repec.org/p/ipc/cstudy/17.html [cited 202020 March].

36. Hernández Romero K. How does Avancemos Work?: Best Practices in the Implementation of Conditional Cash Transfer Programs in Latin America and the Caribbean [Internet]. Inter-American Development Bank; 2016 Feb (Technical note). Report No.: IDB-TN-931. Available from: https://publications. iadb.org/publications/english/document/How-does-Avancemos-Work-BestPractices-in-the-Implementation-of-Conditional-Cash-Transfer-Programs-inLatin-America-and-the-Caribbean.pdf [cited 202020 March].

37. McGuire J. Conditional Cash Transfers in Bolivia : Origins, Impact, and Universality. In San Francisco: Annual Meeting of the International Studies Association; 2013.

38. Sánchez Prada, F, Medellín, Nadin. How does Más Familias en Acción Work?: Best Practices in the Implementation of Conditional Cash Transfer Programs in Latin America and the Caribbean [Internet]. Inter-American Development Bank; 2015. Available from: https://publications.iadb.org/en/how-does-masfamilias-en-accion-work-best-practices-implementation-conditional-cashtransfer [cited 201919 Sep].

39. Flórez CE, Espinosa F, Sánchez LM, Angulo R. Diseño del Índice Sisbén III. Departamento Nacional de Planeación, Dirección de Desarrollo Social, Grupo de Calidad de Vida; 2008 p. 35.

40. Ministerio de Inclusión Económica y Social. Evaluación de resultados e impacto del Bono de Desarrollo Humano (BDH) [Internet]. Coordinación General de Investigación y Datos de Inclusión; 2017. Available from: https:// info.inclusion.gob.ec/index.php/aseguramiento-no-contributivo?download= 469:evaluacion-de-resultados-e-impacto-del-bono-de-desarrollo-humano.

41. Carpio MÁ, Majid F, Laszlo S, Sánchez A, Janzic Z. Programa de Transferencias Condicionadas JUNTOS Perú: Focalización Geográfica (20052017) [Internet]. Available from: https://www.mcgill.ca/isid/files/isid/pb-201906.pdf [cited 201919 Sep].

42. Ponce J, Bedi AS. The impact of a cash transfer program on cognitive achievement: The Bono de Desarrollo Humano of Ecuador. Econ Educ Rev. 2010;29(1):116-25.

43. Sánchez A, Miguel Y, Baanante J. Impacto del programa Juntos sobre la nutrición temprana. Der Reserv Banco Central Reserva Perú Rev Estud Econ. 2012;23:53-66.

44. World Health Organization. WHO Child Growth Standards: Length/Heightfor-age, Weight-for-age, Weight-for-length, Weight-for-height and Body Mass Index-for age [Internet]. World Health Organization; 2006. (Methods and Development Nonserial Publication). Available from: http://apps.who. int/bookorders/anglais/detart1.jsp?sesslan $=1 \&$ codlan $=1 \&$ codcol $=15$ \&codcch=660 [cited 201928 Oct].

45. Corsi DJ, Neuman M, Finlay JE, Subramanian SV. Demographic and health surveys: a profile. Int J Epidemiol. 2012;41(6):1602-13.

46. Filmer D, Pritchett LH. Estimating Wealth Effects Without Expenditure Data or Tears: An Application to Educational Enrollment in States of India. Demography. 2001;38(1):115-32.

47. Rutstein SO. The DHS Wealth Index: Approaches for rural and urban areas. Demographic and Health Survey Working Papers. Calverton, Maryland: United States Agency for International Development; 2008.

48. Poirier MJP, Grépin KA, Grignon M. Approaches and Alternatives to the Wealth Index to Measure Socioeconomic Status Using Survey Data: A Critical Interpretive Synthesis. Soc Indic Res. 2020;148(1):1-46.

49. Jenkins S. Estimation and interpretation of measures of inequality, poverty, and social welfare using Stata [Internet]. Stata Users Group; 2008 Dec. Available from: https://econpapers.repec.org/paper/bocasug06/16.htm [cited 201928 Oct].

50. Jenkins SP. INEQDECO: Stata module to calculate inequality indices with decomposition by subgroup [Internet]. Boston College Department of Economics; 2015. Available from: https://ideas.repec.org/c/boc/bocode/s366 007.html [cited 201928 Oct].
51. Cowell F. Measuring inequality [Internet]. Oxford, UK: Oxford University Press; 2009. Available from: http://eprints.Ise.ac.uk/32554/.

52. Shorrocks AF. Inequality Decomposition by Factor Components. Econometrica. 1982:50(1):193-211.

53. O'Donnell O, O'Neill S, Van Ourti T, Walsh B. Conindex: Estimation of concentration indices. Stata J. 2016;16(1):112-38.

54. O'Donnell O, van Doorslaer E, Wagstaff A, Lindelow M. Analyzing Health Equity Using Household Survey Data; A Guide to Techniques and Their Implementation. Washington, D.C.: The World Bank; 2008.

55. Koolman $X$, van Doorslaer E. On the interpretation of a concentration index of inequality. Health Econ. 2004;13(7):649-56.

56. Arauco VP, Molina GG, Aguilar EY, Pozo WJ. Explaining Low Redistributive Impact in Bolivia. Public Finance Rev. 2014;42(3):326-45.

57. Elisa Flórez C, Rodríguez K. Subsidios sociales, pobreza y desigualdad. Departamento Nacional de Planeación; 2016 Dec p. 16-33. (Observatorio de Familia). Report No.: 8

58. Amarante V, Brun M. Cash Transfers in Latin America: Effects on Poverty and Redistribution. Economía. 2018;19(1):1-31.

\section{Publisher's Note}

Springer Nature remains neutral with regard to jurisdictional claims in published maps and institutional affiliations.
Ready to submit your research? Choose BMC and benefit from:

- fast, convenient online submission

- thorough peer review by experienced researchers in your field

- rapid publication on acceptance

- support for research data, including large and complex data types

- gold Open Access which fosters wider collaboration and increased citations

- maximum visibility for your research: over $100 \mathrm{M}$ website views per year

At BMC, research is always in progress.

Learn more biomedcentral.com/submissions 